\title{
Erratum to: Psychometric evaluation of social phobia and anxiety inventory for children (SPAI-C) and social anxiety scale for children-revised (SASC-R)
}

Sanna Kuusikko • Rachel Pollock-Wurman •

Hanna Ebeling • Tuula Hurtig • Leena Joskitt •

Marja-Leena Mattila $\cdot$ Katja Jussila $\cdot$ Irma Moilanen

Published online: 24 March 2010

(C) Springer-Verlag 2010

Erratum to: Eur Child Adolesc Psychiatry (2009)

18:116-124

DOI 10.1007/s00787-008-0712-x

The author group was published with errors. The corrected author lines are given here.

The online version of the original article can be found under doi:10.1007/s00787-008-0712-x.

S. Kuusikko $(\bowtie) \cdot$ H. Ebeling · T. Hurtig · L. Joskitt .

M.-L. Mattila · K. Jussila · I. Moilanen

Dept. of Child Psychiatry, Child Psychiatric Clinic,

University and University Hospital of Oulu,

P.O.B. 26, 90029 OYS, Finland

e-mail: kuusisan@paju.oulu.fi

R. Pollock-Wurman

Massachusetts General Hospital, Harvard Medical School,

Boston, MA, USA 